\title{
Role of Knowledge and Attitude toward Perilaku Hidup Bersih dan Sehat (PHBS) of Medical Students 2009 Universitas Padjadjaran
}

Sufia Permatasari Syaefullah ${ }^{1}$,Noorman Herryadi $^{2}$, Elsa Pudji Setiawati ${ }^{3}$, Henni Djuhaeni ${ }^{4}$ ${ }^{1}$ Faculty of Medicine, Universitas Padjadjaran, ${ }^{2}$ Department of Forensic and Medico legal, Faculty of Medicine, Universitas Padjadjaran/Dr. Hasan Sadikin General Hospital, ${ }^{3}$ Department of Public Health, Faculty of Medicine, Universitas Padjadjaran, ${ }^{4}$ Department of Public Health, Faculty of Medicine, Universitas Padjadjaran

\begin{abstract}
Background: Perilaku hidup bersih dan sehat (PHBS) is one of the main pillars of preventive measures in Indonesia Sehat and also a strategy to reduce health cost caused by illness based on the desire, willingness, and ability to be able to help themselves in medical aspects. The health provider including a doctor as a community leader should behave toward PHBS which based on adequate knowledge and attitude.

Methods: This study have been conducted in February-November 2012 with cross-sectional design of 152 medical students $7^{\text {th }}$ semester admission 2009 Universitas Padjadjaran, using questionnaires. Data were analyzed using chi-square.

Results: The number of students with good knowledge and poor knowledge were not different (50.7\%vs $40.3 \%)$. Most of the respondens attitude are not in accordance with PHBS program $(p=0.805)$.

Conclusions: Knowledge of PHBS for all medical students needs to be improved and needs to investigated whether there are other factors which affect student attitudes toward PHBS. [AMJ.2014;1(1):86-9]

Keywords: Attitude, knowledge, PHBS, student

\section{Peranan Pengetahuan dan Sikap Mahasiswa Kedokteran Universitas Padjadjaran Angkatan 2009 terhadap Perilaku Hidup Bersih Dan Sehat (PHBS)}

\begin{abstract}
Abstrak
Latar Belakang: Perilaku Hidup Bersih Dan Sehat (PHBS) merupakan salah satu pilar utama pencegahan dalam program Indonesia Sehat serta strategi untuk mengurangi biaya kesehatan akibat penyakit yang berdasarkan keinginan, kemauan, dan kemampuan untuk membantu diri sendiri dalam aspek medis. Pelayanan kesehatan termasuk dokter sebagai pemimpin kesehatan di masyarakat harus mempunyai sikap dan pengetahuan yang memadai mengenai PHBS.

Metode: Penelitian dilakukan pada bulan Februari-November 2012 dengan desain potong lintang terhadap 152 mahasiswa kedokteran angkatan 2009 Universitas Padjadjaran semester 7 dengan menggunakan kuesioner. Data dianalisis menggunakan chi-square.

Hasil: Jumlah mahasiswa yang memiliki pengetahuan baik dan pengetahuan kurang tidak jauh berbeda (50,7\% vs 40,3\%). Sebagian besar responden mempunyai sikap yang tidak sesuai dengan program PHBS ( $\mathrm{p}=0,805)$.

Simpulan: Pengetahuan tentang PHBS bagi semua mahasiswa kedokteran perlu ditingkatkan dan perlu diteliti lebih lanjut mengenai faktor-faktor lain yang memengaruhi sikap mahasiswa terhadap PHBS. [AM].2014;1(1):86-9]
\end{abstract}

Kata kunci: Sikap, pengetahuan, PHBS, mahasiswa

Correspondence: Sufia Permatasari Syaefullah, Faculty of Medicine, Universitas Padjadjaran, Jalan Raya BandungSumedang Km.21, Jatinangor, Sumedang, Indonesia, Phone: +62811234661, Email: sufiapermatasari@gmail.com 


\section{Introduction}

Perilaku hidup bersih dan sehat (PHBS is a behavior that is based on the desire, willingness, and ability of people to help themselves in the field of health and can play an active role in health activities . ${ }^{1}$ The PHBS is one of the main pillars in "Indonesia Sehat" and financing strategies to reduce health cost. ${ }^{2}$ The PHBS is divided into five scopes which are household, health institutions, public places, schools, and workplaces. ${ }^{3}$

Hygiene is not only written in the medical aspect, but also in the aspect of religion, and hygiene itself was written in the oath of Hippocrates.According to some theories of hygiene, it can affect a person's health level, therefore everyone should have clean and healthy living behaviors in order to improve their own health. In fact, many people still do not have awareness about hygiene and healthy behaviors.

Health education is required through individuals who know and understand healthy lifestyle to make people understand and apply PHBS. Individuals who understand healthy lifestyle health resources who canact as a facilitator, communicator, and dynamist in the process of community empowerment. ${ }^{4}$

Theoretically, human resources who are capable of acting as a facilitator, communicator, and dynamist in the process of community empowerment are educated human resources in higher education, in this case is a medical school student who should be able to have knowledge and the attitude to be a community leader, communicator, decision maker, manager, and care provider for the community to be able to manage the health service.

\section{Methods}

The study was approved by the Health Ethics Research Committee Faculty of Medicine, Universitas Padjadjaran and conducted in February-November 2012 which aims to reveal the knowledge and influence of knowledge on attitudes toward PHBS. A survey with cross-sectional unpaired analytical design was used in this study. One hundred and fifty-two fourth year medical students 2009 Universitas Padjadjaran was enrolled according to the inclusion criteria and they have filled in a questionnaire which has been validated.

The independent variable in this study is knowledge, while the dependent variable is attitude. Knowledge-levels are categorized into good and bad. This study categorized attitude as strongly disagree, disagree, agree, and strongly agree. Data that have been acquired are then processed by a computer program using chi square method as data analysis. Then the data are presented in tables and pictures proportionally.

\section{Result}

The respondents were predominantly (69.3\%) female. Good knowledge of PHBS is found in 77 respondents, while remainder had a bad knowledge.

Nearly half of the respondents had an disagree attitude toward of every point PHBS (49\%). The effect of the level of knowledge toward attitude. All the variables were not statistically significant ( $p>0.05$ ) (Table 1$)$.

\section{Disscussion}

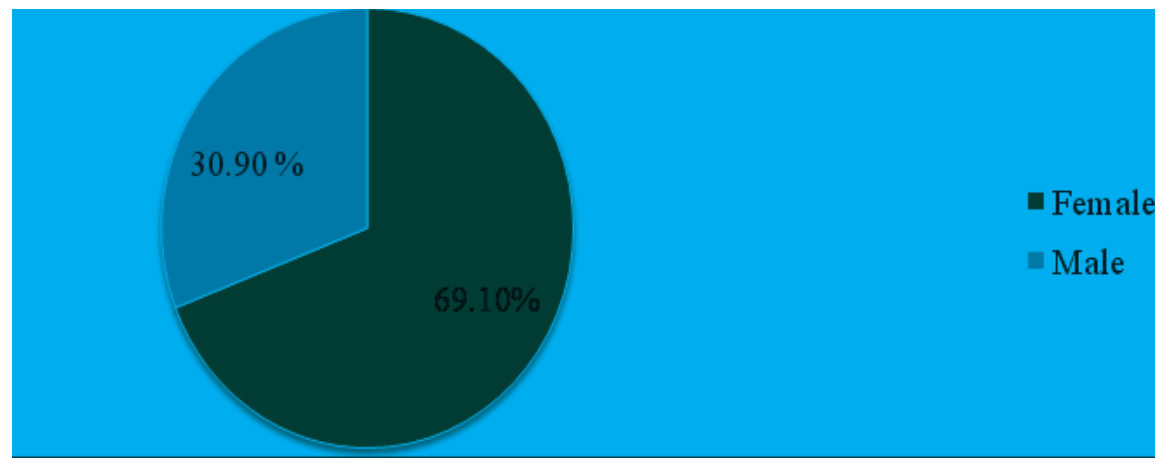

Figure 1 Sex of Respondent

Althea Medical Journal. 2014;1(2) 


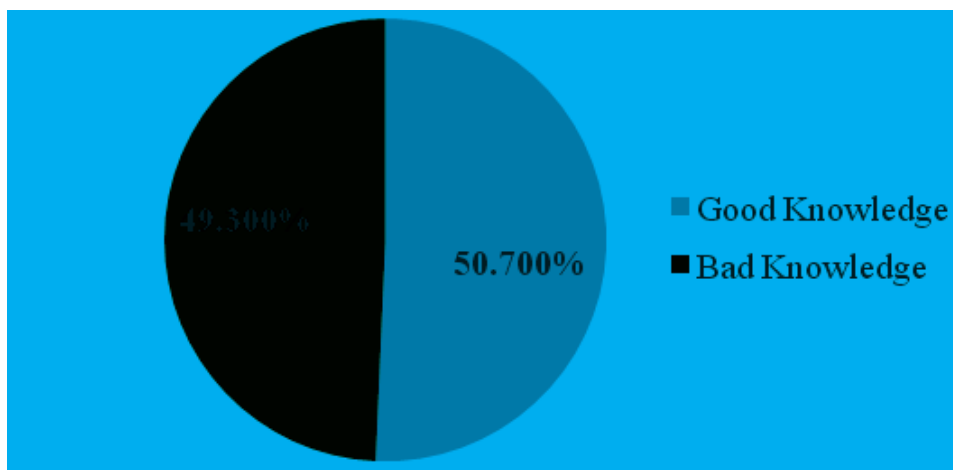

Figure 2 Level of Knowledge of PHBS

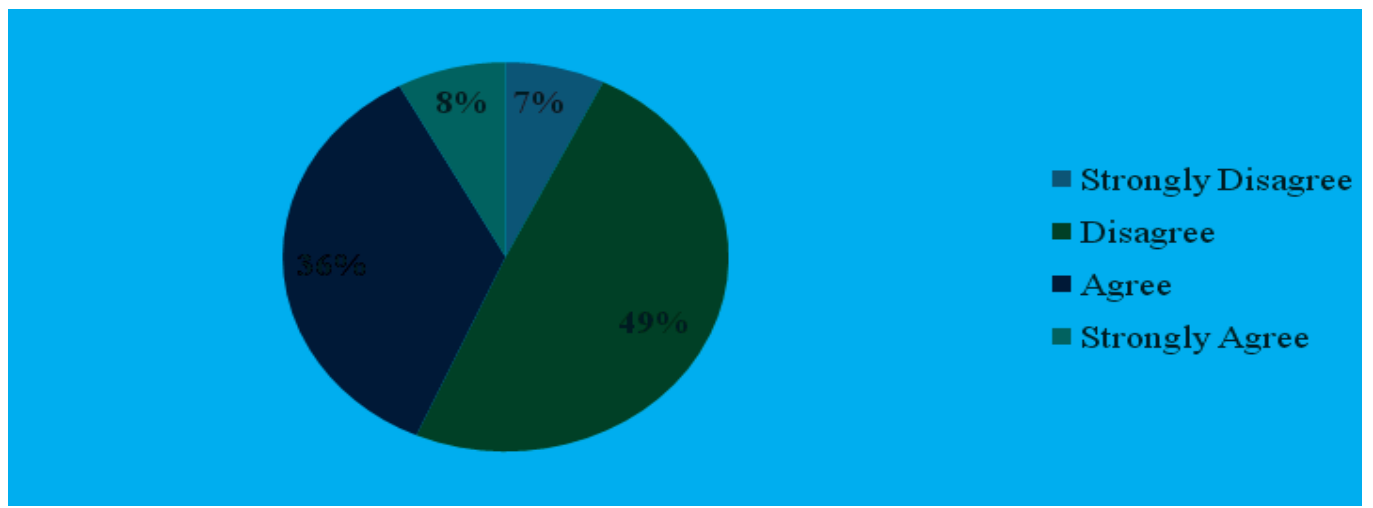

Figure 3 Attitudes towards PHBS

Table 1 Role of Knowledge and Attitude

\begin{tabular}{ccccccc}
\hline \multirow{2}{*}{ Variable } & \multicolumn{5}{c}{ Attitude } & p \\
\cline { 3 - 7 } \multicolumn{2}{c}{ Knowledge } & SD & D & A & SA & 0.805 \\
& Good & 7 & 36 & 26 & 6 & \\
\hline
\end{tabular}

The PHBS is a health promotion program which aims to "Indonesia Sehat", where knowledge, desire, and behavior also play an active role in healthy life realizing optimal health. ${ }^{1}$ The implementation of the PHBS program in the community is expected to increase the level of health as well as the funding for health. This program can be run through the promotion of health and human resources who are necessary to promote health as an educator, trainer, and as a model for the people.

Based on the results, the differences attitude between good knowledge and bad knowledge were not significant. Thus might be due to lack of attention and observation of PHBS as well as health promotion itself. Knowledge is the result of sensing someone who influenced the intensity of attention and perception of the object after observing something. ${ }^{5}$ Knowledge that has an object of study, methods of approach, is systematically arranged, and universal can form science. ${ }^{6}$ Environment such as health promotion can affect a person's knowledge. Health promotion is a process to improve the ability of communities to 
maintain and improve their health. ${ }^{7}$ Based on that theory, in Indonesia health promotion is defined as to enhance community through learning from, by, for, and with the community, so they can help themselves and develop activities resourced communities, according to local socio-cultural conditions and supported by public health policy. ${ }^{8}$ Doctors must have a role in promoting health in order to increase the level of health in communities. Medical students as future doctors is one of the health care providers, should have a good knowledge of PHBS.

Almost half of the respondents had an attitude that did not agree to the PHBS program. Medical students should have towards PHBS program in order to act such as an example to the community indirectly. Knowledge, experience, and environment will influence the formation of attitudes. Attitude is a case or object that is still closed so manifestation of attitude cannot be seen directly but can only be interpreted from its behavior. ${ }^{9}$ Attitude can form a variety of subjective, emotional aspects, and a tendency to behave. ${ }^{10}$

In this study, level of knowledge did not determine attitude significantly on PHBS. This was probably due to some limitations of this study such as lack of opportunity for respondents to ask things that were not understood by the researcher, and there were other factors that played a role on attitude such as environment, behaviors, and other which were not studied yet by researchers.

\section{References}

1. Fauci AS, Weiner C, Braunwald E, Kasper DL, Hauser SL, Longo DL, et al. Harrison's Value Pack $17^{\text {th }}$ ed. New York: McGrawHill; 2008. p. 2277, 2282.

2. Departemen Kesehatan Republik Indonesia. Tahun 2030 prevalensi diabetes melitus di Indonesia mencapai 21,3 juta orang. Jakarta: 2009 [cited 2012 April 30]; Available from: http://www.depkes.go.id/ index.php/berita/press-release/414tahun-2030-prevalensi-diabetes-melitusdi-indonesia-mencapai-213-juta-orang. html.

3. World Health Organization. Diabetes. 2011 [cited 2012 April 30]; Available from: http://www.who.int/mediacentre/ factsheets/fs312/en/index.html.

4. Khan A, Safdar M. Role of diet, nutrients, spices, and natural products in diabetes mellitus. Pak J Nutr. 2003;2(1):1-12.

5. Lim TK. Edible medicinal and nonmedicinal plants: volume 2, fruits. New York: Springer; 2012. p. 239-47.

6. Minaiyan M, Zolfaghari B, Kamal A. Effect of hydroalcoholic and buthanolic extract of cucumis sativus seeds on blood glucose level of normal and streptozotocininduced diabetic rats. Iran J Basic Med Sci. 2011;14(5):436-42.

7. Dixit Y, Kar A. Protective role of three vegetable peels in alloxan induced diabetes mellitus in male mice. Plant Foods Hum Nutr. 2010;65(3):284-9.

8. Ehrhardt C, Kim KJ. Drug absorption studies: in situ, in vitro and in silico models. New York: Springer; 2008. p. 48-50.

9. WHO. Research guidelines for evaluating the safety and efficacy of herbal medicines. Manila: World Health Organization Regional Office for the Western Pacific; 1993. p. 38.

10. Achmad S. Mechanism of membrane transport. Jatinangor: Universitas Padjadjaran; 2006. p. 1-4.

11. Dahlan MS. Statistik untuk kedokteran dan kesehatan. $4^{\text {th }}$ ed. Jakarta: Salemba Medika; 2009. p. 60. 